\title{
Experimental Ethnography: Performativity, Movement, Mediation
}

\author{
Dafni Tragaki \\ Dept. of History, Archaeology and Social Anthropology \\ University of Thessaly, Greece
}

\begin{abstract}
This article discusses the ways the method of videowalk is learned in the context of the seminar "Anthropology of the Senses" with a special emphasis on sound studies, and how it is theoretically introduced as a performative, intersensorial, and embodied ethnographic practice. It explores the potentialities offered by the recent convergences between anthropology and contemporary artistic (audiovisual) production inspired by the "ethnographic turn" in experimental representations of the urban public space. Videowalk is used as a method inviting students to produce cultural knowledge by questioning conventional logocentric (reading and writing) pedagogies and to experiment with reflexive, improvisational, emplaced, and affective mediations of urban life and its changing everydayness. It is a method concerned with the intersections of theoretical knowledge with knowing-in-action, a method privileging the synaesthetic authoring of the public space, its mesh worked trajectories and stories.
\end{abstract}

Keywords: videowalk, emplaced knowledge, senses, performative ethnography and art

\section{Introduction}

The idea to offer a seminar on "Anthropology of the Senses" was formulated in the context of my engagement with the by-now burgeoning field of "sound studies", an interdisciplinary field mainly drawing from ethnomusicology — in particular, Steven Feld's "acoustemology" — and the long-established areas of anthropology of the senses and the body. This is a field also attentive to diverse strands of critical and cultural theory. Sound studies research diversely appropriated sensory ethnographic methodology and experiments with audio-visual forms of cultural representation, such as sound essays and multimedia projects, which often converge with contemporary forms of artistic production. In this article, I am going to explore the potentialities of such convergences and the blurring of boundaries between art and ethnography by focusing on videowalk as a fieldwork method involving filming in movement. This is a method that is taught to undergraduate students at the department of History, Archaeology and Social Anthropology of the University of Thessaly (Volos, Greece).

My interest in the use of video as a fieldwork tool and as a form of mediating cultural knowledge was largely motivated by the strong emphasis placed on film-making as a research technique in the context of my postgraduate studies in ethnomusicology and, especially, by my tutor, John Baily, also a film-maker trained as a RAI documentary film-making fellow at the National Film and Television School (UK). Baily launched in ethnomusicology, among a few others, the teaching of audio-visual fieldwork methods, film editing and the history of ethnographic film significantly contributing to its dialogue with theories of visual ethnography (Baily, 2009; Banks \& Zeitlyn, 2015, p. 144). In the study guide of his award-winning film “Amir: An Afghan Refugee's Musician's Life in Peshawar, Pakistan" (1985) he commented about including a footage of himself soundrecording while walking on the road:i

I am tracked from in front as I walk along Dubgari Road with Satar Khan. Satar explains that Dubgari Road is where all the musicians in Peshawar are based, each group of musicians having an upstairs deyrah (room, or 
a suite of rooms) in this street. This shot was completely set up, and was repeated. In the first take I wore earphones while taking sound with the Nagra. We decided to repeat the shot without the earphones...The justification for including Shots 14 and 16, besides the information they give about Dubgari (which could have been presented in the form of inter-titles), is that they give the film maker an identity, and show the cumbersome equipment which a sound recordist has to manage. (Baily, 1990, p. 8).

This deliberate staging of the sound-recordist and director on film exemplary manifested Baily's theoretical attachment to the principles of observational cinema (Baily, 2009, p. 57-58; Loizos, 1993, p. 85-88). "The observational approach ... must be based on an intimate, sympathetic relationship between the filmmaker and the subject - not the eye of the aloof, detached observer, but of someone watching as much as possible from the inside." (Young $[1975,76]$ in Baily, 2009, p. 57). Screening footage where the technologically equipped filmmaker "takes" the sound purposefully reveals film-making as a complex process of authoring, directing and participatory editing lived realities — a process already discussed in a plethora of writings on ethnographic film. What apparently received less attention, though, is that the director/sound-recordist is also represented on the road, walking-recording at once, "wayfaring", in Tim Ingold's words, in the world of musicians (Ingold, 2011, p. 149). Interestingly, earlier in the film (in Shot 2 according to the study guide) Amir, the musician portrayed in the film, is also introduced to the viewers while walking on the same road. This scene acquaints the viewer with the protagonist, his social surroundings and public space, his space in the city. The handheld camera trajectory materializes the movement of a passer-by mediating, therefore, the immediacy of experiencing pedestrian Amir carrying his step-by-step instrument: "The camera tracks Amir, from behind at first, passes him, and by the end of the shot Amir is seen from in front, as though we are now ready to meet him" (Baily, 1990, p. 7). "ii It is a filming technique that manages to create a sense of "being-there" or, a "sense of place", as Steven Feld famously put it: "as place is sensed, senses are placed; as places make sense, senses make place" (Feld \& Basso, 1996, p. 91). Screening a walking-footage on the same road incites the viewers to imaginatively co-habit that space and cotracking its trajectories together with the protagonist, the director, and the professional musicians dwelling and making their way along Dugbari road in the city of Peshawar, in Pakistan. Eventually, all of them, the road, the people, the objects, are drawn together in the fictional topos and stories of the film, and are subsequently restaged within the unpredictable afterlives the film gains through its screenings in diverse contexts and audiences.

The sense of emplacement generated through movement in the so-called "tracking shots", (here exemplified in "Amir") employed in various scales in cinematography provides a useful starting point for further exploring videowalk as a performative ethnographic practice. It is a practice purposed to familiarize the students with the fictional, intersubjective and reflexive process of filmed life-worlds. Thus alerting them to the basic theoretical commitments of what Stoller famously termed "sensuous scholarship". This necessitates the fusing of the intelligible with the sensible and critically undermining their alleged distinction (Stoller, 1997, p. xv).

\section{Teaching videowalk: anthropology, film and multimodal art}

The representational potentialities of filming in movement have later been further explored by visual anthropologists interested in experimenting with sensory ethnographic methods. For Sara Pink "walking with video" is a method foregrounding corporeality, embodiment and situated multisensorial knowledge. It is a method for creating a "film-place-event" and effectively communicating subjective ways of experiencing and making place both within and beyond academia (Pink 2007, p. 248). "An ethnographic film focus on the walking (i.e. experiencing) body" she argued, "as it moves through space and time, and encounters things and persons, can be interpreted as productive of place-as-event, and creates a filmic representation of place in which it gathers together bodies and things, and time and space through its focus on experiencing sensing body(ies)." (Pink, 2007, p. 248).iii

In this vein of thought, a seminar focusing on videowalk as a research method combined the introduction to core theoretical arguments on the intersection of knowledge, senses, perception, and movement with fieldwork practice in sensory ethnography. During its early stages the seminar introduced the videowalk as a method that places an equal emphasis on recording the visual and the aural. This encourages ways of thinking of sound as a co-constitutive medium of space and the lived world. Walking-filming is discussed as a complex process of gaining tacit knowledge and affectively mediating instances of the everyday. This effectively questions the prevalence of the written word and challenges the intellect paradigm of textual representation (Tragaki, 2013). A productive way for fostering this particular theoretical discussion was the screening of the film "Leviathan" directed by Lucien Castaing-Taylor and Véréna Paravel (2012). iv Produced by Harvard University's Sensory 
Ethnography Lab, the film mediates an immersive experience into the sensory life of the fishing industry at the coastal town of New Bedford in Massachusetts. It is edited in an open-ended, non-linear, and rather poetically and daringly abstracted narrative that is emblematic of experimental ethnography. Its wordless, to a great extent, as scenario intensifies the sense of the objects', species', humans' materiality next to its corporeal and almost hallucinatory camera movements. The film features long underwater shots and sophisticatedly engineered marine and wind soundscapes captured by waterproof recording equipment that is constantly diving in and out the roiling ocean and the Atlantic waves. It nearly exhausts the viewer with thrilling fish-eye views, close-ups, and footages of raw sea-life, the fleshy, bloody dead or dying fishermen's catch, manage to exemplary re-define the boundaries between ethnography and art. In the context of the seminar "Leviathan's" aesthetic/educational value largely rested upon its potential to open a fertile path for students to "feel theory" and for stimulating vivid theoretical debates on sound and embodied, synaesthetic perception. As Escobar noticed, "In a way, it is the ear that renders the image visible in Leviathan, because it is precisely the audio-event that then becomes the visual one (Escobar, 2017, p. 12).v

Moreover, "Leviathan" (among other films included in the course syllabus) stimulated students to think of and use digital media as more than recording technologies purposed to serve the documentation and demonstration of the research output. Rather, students were encouraged to think of the media for actively training multisensory perception and for intimating the world which is becoming "then and there" via the recording media. To that extent, the students were encouraged to experiment, improvise, and consider their own videowalk. This was the course assignment. It was a creative project, and initially students showed a partly reserved response to this task (which they mostly justified as the lack of familiarity with creative learning processes in the course of their institutional education). In the later stages of the seminar their attitudes apparently transformed to be more selfconfident. In several cases students were enthusiastic about their involvement with the project. In order to address educational shortcomings, and to further excite students' imagination and sharpen their "ways of sensing", I decided to include in the syllabus a module focusing on contemporary art's "ethnographic turn" (Howes, 2014).

The "ethnographic turn", in contemporary art scene sharing with ethnographic theory, is a common growing concern with the politics of representation. It has earlier been critically discussed by Hal Foster (Foster, 1995). Foster's seminal essay motivated a skepticism towards the supposed political pretentions of contemporary art and the aesthetic instrumentalization of the subaltern and the alterity as sites of subversion and cultural critique next to the institutional politics of global art marketing (Foster, 1995). Epistemological debates and questions of authority, of who has the right to represent what, how and in what context, have of course been perennial in anthropology, among other disciplines. Yet, perhaps this is exactly also the challenge in the sort of art/anthropology reciprocities discussed in this seminar: to creatively explore, invent and perform novel ways of unraveling representation as a strategy; to make it known as a process involving an author designing, experimenting, failing, re-drawing, improvising, and mediating lived experiences as relational and situated practices of knowing the world. . $^{\text {i }}$

Undoubtedly, such reciprocities signaled a crucial shift in anthropology's disciplinary quests and representational endeavors. Yet, it is also important to bear in mind that long before anthropology's flirting with contemporary art and artists, a sort of ethnographic sensibility was apparently already evident in the work of $20^{\text {th }} \mathrm{c}$. modernist composers. They critically engaged, and no less played with, the phantasmagoric real of urban life. For instance, we listened in the seminar room to Pierre Schaefer's "Etude aux chemins de fer" (1948). Still today, its intriguing sounds often provoked surprised reactions on the part of many students ("is this a musical work?"). Schaefer was originally inspired by his vivid interest in researching noise and in experimenting with new audio recording and editing techniques. This research laid the foundations for what was later termed "musique concrète". vii "Etude..." was composed by a collage of studio-manipulated field recordings of train engines made at Batignolles station in Paris. One can also listen as an essay enabling the unconscious alignment with the excessive rhythmologies of the industrial postwar Paris' everydayness, or, as a device for "entrainment", following De Nora, into the beats of technological progress (De Nora, 2000, p. 77-78). Of particular interest for sensory theory is Schaeffer's ideas on "reduced listening", a term that he coined in order to describe a technique of listening where sound is appreciated and felt as a materiality separated from its source. In reduced listening "sound no longer appears as a medium or placeholder for 'some other thing"' (Kane, 2014, p. 28). In a way, Schaeffer dissociated his work from a documenting project stressing instead the pleasure of imaginatively playing with the rhythms, textures and timbres of the massive, fast-travelling, steel-made machines of the Parisian mundane and thus subverted pre-conceived ways of listening and making sense of them. At the same time, this inverted compositional processes and questioned the notion of "musical work" in Western European modernity. 
At that time, however, anthropology apparently expressed little interest in such sensory experimentations or in contemporary art altogether. With the exception of Steven Feld's foundational ethnographic study of rainforest soundscapes in Papua New Guinea (Feld, 1982), it also remained largely indifferent to the "World Soundscape Project" (WSP) founded by Murray Schaffer, researcher, composer and sound theorist based at Simon Fraser University. This research project launched in the late 1960s and early 1970s. WSP was a groundbreaking collaboration among researchers/electroacoustic composers/sound theorists originally joined by their concern with urban noise pollution and the preservation of dying sounds. viii Though several of their core theoretical arguments were later critically re-visited, their recording projects and writings innovatively addressed at once the artistic and the scholarly. They exercised a significant impact on soundscape composition and the sort of methodologies employed, gradually gained legitimacy in, what was later termed, "sound anthropology" and sound studies in general. WSP and its key analytical concepts were also discussed in the seminar in order to raise the problematic of its binary, ethnographic/artistic outcome and in particular, for familiarizing the students with Hildegard Westerkamp's early experimentations with the soundwalk method and her call for "attentive listening" (Westerkamp, 1974; 2007). For Westerkamp, learning to attentively listen is purposed to "rediscover and reactivate our sense of hearing" occurring in the process of taking-a-walk-listening to the sound environment in terms of a musical composition.

This early focus on sound perception/walking, however, left "movement" and the "body" rather undertheorized. Thinking and teaching videowalk as a sensory ethnography method also necessitated, though, the students' familiarization with thinking of walking itself as an affective, multisensorial corporeal practice. For this purpose, the syllabus also placed special emphasis on some of the key aspects of Tim Ingold's phenomenological anthropology. Taking his line of thought from Bourdieu's conceptualization of habitus and bodily bexis, Ingold departed from anthropological readings of "techniques of the body" (though acknowledging Mauss" innovative theoretical insights) as processes learned and inscribed though cultural education. Instead, he suggested that a way of walking "is itself a way of thinking and of feeling, through which, in the practice of pedestrian movement, these cultural forms are continually generated." "But could we not also put this proposition in reverse, to argue that thinking and feeling are ways of walking?" (Ingold \& Vergunst, 2008, p. 93-94). The sensory experience should thus be understood as more than "a vehicle for expression of extrasensory, cultural values" (Ingold, 2000, p. 156). In this way, Ingold critically challenged the subject/object dichotomy and diverted from the sort of anthropological analysis of embodiment processes which "tend to forget that the body itself is grounded in movement". He instead insisted on the idea (drawn from Sheets-Johnstone's philosophical writing) of "walking as foundational to being a body." "Walking is not just what a body does; it is what a body is" (Ingold \& Vergunst, 2008 , p. 2-3). Moreover, Ingold revisited the modernist distinction between meaning and perception arguing for the immediacy of the sensory experience and mobility as modalities of becoming, of sensing and knowing the world.

During the course of the seminar particular emphasis was put on his concept of "wayfaring": a term describing the embodied experience of place as a process of continuous movement along trajectories where place emerges as a knot of entwined trails. In Ingold's words, lines interweaved in a "meshwork" in which life is lived (Ingold, 2007; Ingold, 2011, p. 148). Students were encouraged to design their videowalk projects as wayfaring projects, as the making of trails narrating their own stories, edited, sensed and lived by the video-maker. Their accumulated knowledge of urban space (the city of Volos in this case) became one "generated in movement" and "integrated alongly", while moving through and around the city, from and to the city making memories and stories (Ingold, 2011, p. 154). Practicing wayfaring thus challenged the students to inhabit and intuitively perform the city as a meshwork of trajectories. They came to know videowalk as a form of cultural improvisation (see Ingold \& Hallam, 2007), or as a sort of ethnographic flaneurie. It was a way to delve into the city's psychogeography and of practicing a derive, as Debord put it in the 1960s. They were playfully immersing in, and allowing themselves to be captured by the staging of constantly changing human life-worlds in the urban terrain. Getting to know the experience of improvisation draws further attention to the performativity of videowalk: the unexpected deviations inspired by accidental encounters (by a smell, for instance, or a strange sound), returns, in situ revisions of the original planning, or the encounter with relatively unexpected scenes and vistas. More than an initiation to a field practice where cultural space is subjectively (re)produced, the performativity of videowalk can also raise awareness among the students of the randomness, elusiveness and, occasionally, erratic quality of affective knowledge gradually embodied there and then and, no less, to realize that knowledge can also be gained beyond the realm of textuality (namely the long-established method of academic learning based on reading and writing). Eventually, videowalk as a performative ethnographic project in place-making became an exercise in subjectification through walking-sensing-mediating. Performing the storied lines of the urban meshwork was inevitably a reflexive process of becoming along the palimpsest and knots of its space. A space in this case 
perceived as a fluid, boundless, shifting terrain constantly emerging step-by-step and contingently inviting the dialectic emergence and likewise (re)editing of the Self as an open-ended, negotiating and negotiable experimental project of memories, senses, movements, one contingently (re)produced apropos and because of the filmed trajectory.

As most of their projects took place on the sidewalk, students were moreover encouraged to reflect upon Brandon Labelle's theorization of the sonic body as a "journey-form" (Labelle, 2010, chapter 3). Labelle appropriated Nicolas Bourriaud's "relational aesthetics" and, especially, his notion of "journey-form". It invites us to imagine the walking body as an agent of a compositional practice and contemporary cultural form taking place in progression (as a journey) "aimed at performing the very conditions of displacement" and fashioning "an endless itinerary out of the transient condition one is already called to occupy", "whose rhythm stitches the local body into a greater network of relational exchanges". Labelle's "sonic body" refers to this "effective dislocation and reconfiguration of the body" as a "step by step journey-form" emerging within the transformative dynamics of listening while moving along the acoustic territories of the city (Labelle, 2010, pp. 106 -107). The walking agency is eventually involved in stepping as a political action, a case which is further demonstrated in the seminar through an emphasis on reflecting upon specific historical events and cultural practices. It also is seen in terms of politically-charged walking events, practices, and citizenships made in the public sphere. The selected examples included the screening of riots (such as the violent protests against austerity measures in Greek city streets), military marches (the annual national marches, for instance, organized for commemorating the "national struggle for Independence"), religious processions (pilgrimage, for instance, as a ritual process of walking-believing-worshiping), funerals (such as, the New-Orleans walking-dancing-musicking jazz funerals) next to a selective exploration of cross-cultural relevant ethnographic publications: Steven Feld's valuable ethnographic insights of spatial/temporal sensory interplays in Papua New Guinea's tropical forest, Sara Pink's study of Cittaslow movement (Pink, 2008), Hayden Lorimer's and Katrin Lund's (2008) study of hillwalking in Scotland. The course's suggested bibliography also included Bruce Chatwin's ethnographicallybounded travelogue The Songlines (1987), an inquiry into the interrelation of nomadism with Aboriginal song in Australia, a book that was translated into Greek and apparently fascinated a number of students.

An essential text for the seminar was Michel de Certeau's theory of walking in the city as "a process of appropriation", that is the forerunner of most recent theories on walking. For de Certeau, the city-text is brought to life through the pedestrians "long poem of walking" (De Certeau, 1984, p. 101). His famous definition of walking as a practice of "lacking a place", "makes the city itself an immense social experience of lacking a place" (De Certeau, 1984, p. 103). Pedestrians, as the students are recurrently reminded, are the authors of the urban text that is narrated as an ever dispersing ensemble of possibilities, encounters and diverse viewpoints rendering the urban fabric to a constantly transforming nexus of experiences. In order to inspire further reflections upon walking practices as creative/sensory subjective ways of authoring/mediating space (as well as, in order to facilitate the "digestion" of walking theory ) students were introduced to the videowalk projects by the contemporary multimodal artists Janet Cardiff and George Bures Miller. ${ }^{\text {ix }}$

Among the projects screened and analyzed in the seminar room was the "Alter Bahnhoff videowalk" (26 min.) originally commissioned for the art exhibition dOKUMENTA(13) held in 2012, in Kassel, Germany. Overall, Miller and Cardiff's walks involve the design and recording of trajectories made by the artists who guide the participants into alternative, fictional ways of inhabiting, sensing, moving, and intimating spaces (such as train stations, libraries, or public parks). At the designated starting point of the itinerary, participants are offered headsets and the necessary digital video/sound equipment (an i-pod in the case of "Alter Bahnhoff videowalk") uploaded by the artists with the prerecorded video of the trajectory that they are about to follow. They are then guided through Cardiff's softly narrating voice and follow a scenario that opens up a seemingly similar yet alternate world. It is a world purposefully blending the actually lived reality with its mediated artistic manipulation and unconsciously confusing spaces, temporalities, memories and senses. Following Cardiff, such playful merging of the virtual/physical "create(s) a new world as a seamless combination of the two" (Schaub, 2005, p. 15). It is one which is experienced as a hybrid practice of sensory displacement and (re-)emplacement. Such hybrid experience is guided by the rather confessional "grain", in Barthes' terms, of Cardiff's voice materializing an inward-coming agent (at once coming from the self and addressing the self) intended to intuitively colonize the user's body and its imagination. There is a shot, for instance, of a group of street brass musicians, a euphonium and tuba player, playing a song resonating throughout the train station's monumental architectural acoustics. "Do you see the musicians?" the voice asks. "They're between the pillars now". This "now" defines a synaesthetic moment of synchronicity, where the "now" of the video recording comes into tension with the "now" of the user's temporality of walking. This is a state of aporetic in-betweeness. Wandering 
across a parallel acousmatic space/time, the user is becoming increasingly aware of the friction between Cardiff's mediated world and the world existing beyond the headset. Later on, the user hears the recorded voice of an oldman recollecting the traumatic moments of the station's wartime history. Soon after, Cardiff's voice colored with a tone of curiosity almost resembling the voice of an ignorant wanderer, invites the user to approach "this trolley thing" (the Holocaust memorial staged in Kassel's station), before heading to platform 13, the point of Jewish population deportation to Theresienstadt and Majdanek concentration camps. The old-man's voice with the German accent, therefore, is purposed apparently to prepare the user for the next mediated event: "...the sound was terrible. Bombs fell, houses collapsed and all around me was fire, every house was burning, and the next morning bodies lying in the street, arms, legs, everything was lying around." In fact, the "trolley thing" is an old wagon serving as a Holocaust memorial artwork; an artwork filmed and subjectively (re)enacted within another artwork, that is the videowalk. The footage escalates to a zooming-in to the page-turning hand movement of an archival publication with black-and-white portrait-photos of the victims. Cardiff's videowalk is besides highly concerned with processes of memory-work and there are occasional shared personal reflections and fleeting recollections embedded in the scripted narrative seductively scripting the walker's experience in the old train station. "Memories is like a different form of travelling", Cardiff's gentle voice confesses at some point, "it's like filling a suitcase that we pool behind us, and we open and close when we need to". Several minutes later she returns with a troubling question on the same issue: "How do people deal with memories they don't want? Do they just close the suitcase?"

Cardiff and Miller's artistic treatments of memory, movement, time, and the emplacement of the senses is purposed to stimulate students' imagination during their early experiments with the method. Eventually, the experience of the videowalk becomes an immense experience of historical and ontological suspension. Any fixed definition of what it means to perceive and to be present dissolves and disperses "subjecting the viewer to a unique sense of presentness in all its temporal complexity" (Koepnick, 2017, p. 235). The videowalk designed to take place in the old train station also becomes a gesture to history, not as a ritual memorial service, but as an affective reflection and in-situ, intuitive recollection of the past which is accidentally surfaced (almost in the form of a free-association) in the ways we inhabit the present. As such, the videowalk serves as a paradigm for an alternative way of coming to know history.

The discussion of Cardiff and Miller's videowalks in the seminar thus addressed, next to epistemological issues of sensory knowledge, movement, embodiment and mediation, the actual processes of designing, recording and editing a videowalk. Besides, one of the main tasks targeted by the seminar was learning to think of the practice of digital mobile recording as technologies of relational aesthetics. For Cardiff, binaural recording was "a way to be in two different places at once. I was able to stimulate space and time travel in a very simply way" (Schaub, 2005, p. 5). Cardiff's binaural recordings materialize a three-dimensional sphere of sensorium staging her recorded voice within a multi-layered audile realm that is intimately inhabited by the videowalk user. Combined with extended camera-takes and the first-person perspective such techniques and filming aesthetics activate the participant's attunement with the rhythms and hybrid textures of the recorded trajectory and its corresponding realities. It is also a sort of attunement strategically effecting momentary distractions, producing a disoriented and, at times, accidental "wordling", as Kathleen Stewart would put it (Stewart, 2011, p. 449), performed within interlocking platforms of place-making and events. Both the aesthetic of the long-take and the sophisticated binaural recording techniques potentially stimulate the user's fastening to the film's diegetic space. The filmed and storied trajectory is thus understood as an open-ended artifact co-authored by the user, who at the same time becomes part of the object/video, its contingencies and ephemeralities.

Moreover, teaching videowalk proved to be an appropriate pedagogy for discussing the poetics of ethnography in terms of film-making by encouraging students' hands-on relationship with the recording media as ethnographic tools. Instead of insisting on technical issues, the emphasis in this case was placed on recording and editing as sensorial forms of authoring an ethnographic fiction, structuring time and space, staging events and agencies and making a storyline, one that is hand-made and experientially understood by the student as a selective, changeable, fallible, contingent, emergent, situational, opportune process (and I am obviously inspired by Feld's notion of acoustemological knowledge; Feld, 2015).

\section{Epilogue: the videowalk method as a pedagogical tool}

Teaching videowalk as a method for training students in sensory ethnography offers a challenging opportunity to engage the students in forms of embodied learning through the hands-on experience of field recording on the 
road. Students are invited to invent, record and create their own mediations of the world "out there". Students exhibit their ways of appropriating, sensing, and making sense of the city streets, and producing intersubjectively and dialogically edited stories and scripts of the everydayness. Coupled with the theoretical discussions presented above they are engaged in the making of a personalized form of knowledge and the development of ethnographic sensibilities through the pleasure gained by playing with their "data". They are transformed from consumers of texts (the conventional method of accessing knowledge) to creative agents and negotiators of a bodily knowledge also accumulated "out there". To that extent, teaching videowalk becomes more than a pedagogical tool. It is a way to re-address knowledge and to privilege, following Feld, "knowing-in-action", "knowing-with" and "knowing-through" the sensible (Feld, 2015, p. 12). It thus promotes a rather unsettling form of knowledge as an intersubjective, dialogic, and shared experience which can also become a "technique du corp", as Mauss famously put it. Such forms of knowledge foreground creativity and the developing of democratic learning environments, where the professorial monophonic authority is mitigated by polyphonic exchanges among everyone participating in the seminar. They encourage the student to become more an actor, and less a disciple, partaking in collaborative-platforms of debating, experimenting with and co-authoring ethnographic audiovisual texts. All the while, the videowalk method can stimulate students to "feel theory", intriguing them to come to terms with the abstract complexities of the anthropological/philosophical framework of the seminar, while providing the teacher with generous material for structuring the seminar discussions (film, music, contemporary art). As such, it can contribute to a critical re-appraisal of the university as an institution withdrawn from the "life out there" - that is apparently a commonplaced impression among students - and offer an alternative paradigm for academic ways of learning which are more openly channeled with the public sphere beyond university's institutional walls.

\section{References}

Baily, J. (2009). The Art of the 'Fieldwork Movie': 35 Years of Making Ethnomusicological Films. Ethnomusicology Forum, 18, 1, 55-64.

--- (1990). Film Guide for Amir'. Documentary Educational Resources, http://www.der.org/resources/guides/amir-study-guide.pdf

Banks, M. \& Zeitlyn, D. (2015). Visual Methods in Social Research, London: Sage Publications.

De Certeau, M. (1984). The Practice of Everyday Life. Berkeley, Los Angeles, London: Univ. of California Press.

De Nora, T. (2000). Music in Everyday Life. Cambridge, Cambridge Univ. Press.

Escobar, C. (2017). The Colliding Worlds of Anthropology and Film-Ethnography. Anthrovision, 5, 1, 1-17.

Feld St., \& Basso K. (1996). Senses of Place. Santa Fe, New Mexico: School of American Research Press.

Feld, St. (1982). Sound and Sentiment. Birds, Weeping, Poetics and Song in Kaluli Expression. Philadelphia: Univ. of Pennsylvania Press.

--- (2015). Acoustemology. In D. Novak and M. Sakakeeny (eds), Keywords in Sound, Durham, NC: Duke Univ. Press, pp. 12-21.

Foster, H. (1995). The Artist as Ethnographer? In. G. Marcus and F. Ryers (eds), The Traffic in Culture. Refiguring Art and Anthropology. Univ. of California Press, pp. 302-399.

Howes, D., \& Classen, C. (2014). Ways of Sensing. Understanding the Senses in Society. London and NY: Routledge.

Ingold T., \& Hallam, E. (eds) (2007). Creativity and Cultural Improvisation. Oxford: Berg.

Ingold T., \& Vergunst J. L. (2008). Ways of Walking. Ethnography and Practice on Foot. Aldershot: Ashgate.

Ingold, T. (2000). The Perception of the Environment. Essays on Livelihood, Dwelling and Skill, London and NY:

Routledge.

--- (2011). Being Alive. Essays on Movement, Knowledge and Description. London: Routledge.

--- (2007). Lines. A Brief History. Cambridge, MA and London: Harvard Univ. Press. 
Koepnick, L. (2017). The Long Take. Art Cinema and the Wondrous. Minneapolis, London: Univ. of Minnesota Press.

Kane, B. (2014). Sound Unseen. Acousmatic Sound in Theory and Practice. Oxford: Oxford Univ. Press.

Labelle, B. (2010). Acoustic Territories. Sound Culture and Everyday Life. London: Continuum.

Loizos, P. (1993). Innovation in ethnographic Film. From Innocence to Self-Consciousness, 1955-1985. Chicago: Chicago Univ. Press.

Lorimer, H., \& Lund, K. (2008). A Collectable Topography. Walking, Remembering and Recording Mountains. In T. Ingold \& J. L. Vergunst (eds), Ways of Walking. Ethnography and Practice on Foot. Aldershot: Ashgate, pp. 185200.

Pink, S. (2007). Walking with Video. Visual Studies, 22, 3, 239-252.

--- (2008). Mobilizing Visual Ethnography. Making Routes, Making Place, Making Images. FQS 9, 3. http://www.qualitative-research.net/index.php/fqs/article/view/1166/2575

Rikou, E., \& Yalouri E. (2017). Learning from Dokumenta. A Research Project Between Art and Anthropology. In N. Buurman and D. Richter (eds), 'Dokumenta. Curating the History of the Present', On Curating, 33, 132-138.

Schaub, M., (2005). Jannet Cardiff. The Book of Walk, Koln: Walther König.

Schneider, A., \& Wright, C. (eds) (2013). Anthropology and Art Practice, NY: Bloomsbury. --- (eds.) (2017). Alternative Art and Anthropology. Global Encounters, NY: Bloomsbury.

Stewart, K. (2011). Atmospheric Attunements', Environment and Planning D: Society and Space, 29, 445-453.

Stoller, P. (1997). Sensuous Scholarship. Philadelphia: Univ. of Pennsylvania Press.

Tragaki, D. (2013). Meshwork City. Trails, Sounds, Senses, Words. Proceedings of the Conference Hybrid City. Subtle Revolutions. Athens: Univ. Research Institute of Communication.

Westerkamp, H. ([1974] 2007). Soundwalking. In A. Carlyle (ed.) Autumn Leaves. Sound and the Environment in Artistic Practice. Paris: Double Entendre, p. 49.

\section{Notes}

i “Amir: An Afghan Refugee's Musician's Life in Peshawar, Pakistan” received the Award of Excellence by the Society for Visual Anthropology (1989) and the Prix Special de Jury, BilanEthnographique, Musee de l' Homme (1986).

ii Shots of walking Amir are included elsewhere in the film (Shots 4, 43, according to the study guide).

iii Pink borrows Edward Casey's ideas on place as event.

iv The trailer is available at https://vimeo.com/45252172. Accessed on January 18, 2019.

"See also the special issue of Visual Anthropology Review, 2015, 31(1) on "Leviathan".

vi Anthropologists have increasingly been seeking collaborations with artists resulting in the production of projects based on ethnographic research methods, which are hosted in major cultural institutions. See, for instance, the conference organized by Tate (UK) "Fieldworks. Dialogues Between Art and Anthropology" https://www.tate.org.uk/context-comment/video/fieldworks-dialogues-between-art-and-anthropology-day-1; in Greece, the research project "Learning from Dokumenta" (Rikou and Yalouri 2017). Also see relevant publications, such as Schneider and Wright (2013) and Schneider (2017).

vii Available at https://www.youtube.com/watch?v=N9pOq8u6-bA. Accessed on January, 25, 2019.

viii Schaffer referred, though, to the influence of Marshal MacLuhan's notion of "acoustic space" inspired by Edmund Carpenter's study of "Eskimo" space concepts. More details on WSP are available at https://www.sfu.ca/sonic-studio-webdav/WSP/index.html. Accessed on January 23, 2019.

ix For further information visit the artists' website, https://www.cardiffmiller.com/. Accessed January 29, 2019. 